viscous when emitted, and crystals of chloride of ammonium were found in the vicinity of the craters. Only slight traces of the volcanic action remain now, where warm air arises from the thicker layers of lava.

Prof. Johnstrup is engaged at present in the preparation of maps showing the successive deposits of lava from the older eruptions, as well as from the more recent. The Hlidar range, hitherto regarded as a palagonite formation, was found by him to consist of trachytic masses, a more ancient, and in Iceland rarer, formation than palagonite.

In connection with Prof. Johnstrup's Report we may refer to Mr. Watts's interesti ig narrative of his journey across the Vatna Jökull. ${ }^{1}$ Mr. Watts's name is already well known in connection with recent exploration iti Iceland. He has for long had a strong desire to cross the Vatna Jökull, and at last succeeded. We infer--for his narrative is almost innocent of dates-that the feat took place in the summer of 1875 . The preparations made remind one of those necessary before setting out on an Arciic expedition, and the whole journey bore a strong resemblance to those sledge journeys we read of in connection with the recent polar expedition. There were sledyes, tent, sleeping bag, pemmican, and similar stores; frost-bites, snow-storms, and weary detentions for favourable weather and ground. The Vatna Jökull, we learn from $\mathrm{Mr}$. Watts, is a vast accumulation of volcanoes, ice, ano snow, covering an area of over 3,000 square miles in the south-east of lceland. It is a plateau of from 4,000 to 6,000 feet high, is surrounded on all sides by volcanic mounrains, and gives birth to glaciers on various sides. On the south especially it seems to be advancing, and there the glacier may soon reach the sea and give birth to miniature icebergs. Mr. Watts crossed at the east side, and after suffering considerable hardships he and his party reached the farm of Grimstadr, in the north of Iceland. From here Mr. Watts returned southwards to the northern edge of the Vatna jolkull for the purpose of examining the Oskjagja, a huge and active crater on the south of the Askja, or DyngjufjaIl, referred to by Prof. Johnstrup. Mr. Watts yives many interesting and important details concerning this mountain and the desolate country in its vicinity, covered with pumice dust and other products of eruption. Mr. Watts also visited the region around the Myvatn Lake, near which are the sulphur deposits which a company was started to work. After visiting one or two places on the nurth coast he returned to Reykjavik right across the centre of the country. Notwithstanding the defects of style, the want of dates, and occasional vagueness, Mr. Watts's narrative is a really valuable and interesting contribution to a knowledge of the physical geography of Iceland, and he has the honour to be the first, so far as known, to have crossed the great Icelandic waste.

\section{THE ANTIQUITY OF MAN}

$\mathrm{T}$ the number for May 24 we gave abstracts of the papers read by Professors Dawkins and Hughes, and Mr. Tiddeman at the Conference on the subject of the Antiquity of Man at the Anthropological Institute, and this week we give a report of the discussion which followed the reading of these papers, the remarks of the various speakers, we may state, having been revised by themselves.

Prof. Busk wished to explain, before the discussion commenzed, the circumstances connected with the interesting fragment of bone, for the determination of which he was personally responsible. This "bone of contention" was represented by the cast which he held in his hand. He was surprised that such a large superstructure had been raised upon that particular piece. It was merely a fragment, evidently of a fibula, one of the most variable bones in the body. It was received by him, together with a large collection of other remins from $\mathrm{Mr}$. Tiddeman, " "Across the Vatna Jökull; or, Scenes in Ic -land," by William Lord and for a long time remained an insoluble problem. At last, after many conjectural delerininations by himself and others, Mr. James Flowtr, the well-ktsown articulator to the Royal Col lege of Surgeons, discovered in the College a human fibula of unusual size, and with which, as he pointed out, the Victoria Cave bone corresponded in many particulars. This determination, with the reasms for it, and illu-trated by figures, was published in the Fon'nal of the Insticute. At the same time Mr. Bunk was perfectly.open to he convinced that it might be ursine. But alh:ugh Prof. Boyd Dawkins had been good enough to show him bones of fossil bears of surprising size, none of them quite came up to the one in question. Nor at Toulouse, where there is such an enormous collection of ursine remains, did Mr. Busk observe any of corresponding dimensions. He was himself still disposed to regard the specimen as a fragment of an abnormally large human fibula, but thought that at present it would be unsafe to build any strong conc usions upon it.

Pfor. Rolleston strted that in digeing out a British skeleton he came upon a fibula standing vertically. They went on and he took out every bone with nis own hands and they came to a skeleton, contrac ed in the ordinary British way, which was whole, minus that one fibula. A man is put into the ground with his flesh and bones all upon him, the flest decays, the stones get upon him, the bones are loose and consequently the fibula gret: disturbed. Even granting that the one before them was a human fibula he would lay less streis upon it than on any other bone. In the Gibraltar Cave series the fibula, owing to their liability to displacement, were very often missing. He did not in the least dispute the antiquity of the deposits in the Victoria Cave. With respecl to the reindeer and the hippopotamus, they might judge somelhing trom what they saw in the life and in the flesh. He had seen the hippcpotamus walking about in very cold weather in the Zoological Gardens seeming extremely comfortable, and the rhinoceros and reindeer the same. Mr. Evelyn, of Wotton, had kept reindeer alive for considerable periods in England. At the time of Julius Cæsar the reindeer lived in Germany. At the present time the reindeer was the food of the tiger in the Isle of Saghalien, North of Japan. There the tiger, which has a black and thick fur, crosses the ice after the reindeer. The skull of a young hippopotamus was found in England, showing that the hippopotamus really did live here and breed here too. Hence, mammals were not good indicators of temperature.

Prof. Prestwich referred to the observation of the president, that to consider the present subject thoroughly required the knowledge of the palxontologist, the anthropologist, the archreologist, and the geologist. He thought that it specially concerned the geologist with regard to the sequence of events. The palæontological evidence hardly presented sufficient differences. We had to deal with the sequence of man from his first appearance in time geologically to the present period. He would confine himself to the evidence in the south of England and in the north of France. In the south of England it was particularly clear and decisive; the datum line was distinct. It was afforded by the deposit of the boulder clay, which ranged as far south as London. That represented the glacial period. The post-glacial period he con. sidered to be subsequent to the period of the deposit of the boulder clay. Most of the discoveries made in this country have been made in the districts of the south which have been covered by the boulder clay, and it is in the drift and gravel of the valleys excavated in the boulder clay of those districrs that the flint implements have been so largely found; therefore he believed that in all that area man is of post-glacial age. If we got two levels on either side of a valley, so many feet above sea-level, with the boulder clay cut off on either side, then of course the débris at the bottom of the valley would consist of gravel, and so on, derived from materials which had been formed by the destruction of the several strata which originally traversed that valley. The materials so spread out were necessarily newer than the boulder clay; consequently man in the valleys was post-glacial. There were sometimes two or three successive levels of gravels in those valleys. If a valley was excavated to a rertain depth, and a deposit was formed in which they could find no traces of the existence of man, whilst at another and deeper level fint imple. ments were found, then man was introduced in that place only when the valley was excavated to its greatest depth and the gravel was spread out on the site now nearly occupied by our present rivers. Unfortunately the mammalian remains of those nearly connected periods were so alike that it was impossible to determine rom the distinction of age. Bone caves were also found on the sides of valle $s$ and in districts where there was scarcely any 
boulder clay, and we were then left to the palæen tological evidence. With regard to the possible correlation of other deposits found in the south of England with the deposits which preceded the glacial period in the nurth, there was eviclence in both areas of the land having been inhabired previous to the bou'der clay period by animals which were likely to serve as the food of man. There was no $c$ priori reason why man shouid not have existed before that peri,d. Much would have to depend upon that complete palxontological evidence which porsibly $\mathrm{Mr}$. Tiddeman might have at sume future period to bring before them rather than upon geological postion. He was disposed to consider with Mr. Tiddeman that the cave he was now investigating might be of pre gla: ial age. He thought that the tvidence rather tended to shu, it was pre-glacial, but it was not conclusive. What might be decided ripon that particular point must, however, deptnd upon further research. Taking again the valley of the Thames, we found flint implements in terraces raised some twenty, thirty, or forty feet above the preserit level of the river. At Keculver we found such evidence of the exi-tence of man in a gravel eighty feet high, but as we ascended the valley we found the flint implements confined to the lower levels. At Reading no fint implements or mammalians are found in the high-level gravel. So also in the neighbourhood of Oxford mammaiian remains and implements are found in the low-level gravel but none in the higher. Thus at the entrance of the Thames valley near to France we find evidence of man in the later bieh.level gravels, but man had not then penetrated into the Upptr Thames valley. It was evident that at the period that those hither teriacts were deposited in the upper valley of the Thames as far down as Maidenhear, very cold conditions pervaded, though post-glacial to the boulder clay. In the neighboulhood of Oxfurd there have been found in this upper gravel boulders of several tons in wight which had been carried from a very long distance, and he had recently observed in the neighbourhood of Reading sime high-level gravel resting upon an ice-pitted surface of stiff clay in which there was no calcareous matter, presenting that sort of section (drawing it on the black board). A surface the size of that room was exposed. It seemed to him, however, that with respect to p:e-glacial man there was an important "suspense account" now accumulating. In France an large series of observations had been made by competent observers, and it would not do to ignore the points they had brought forward. He had some reason now to believe from his own observations that there was evidence of man being preglacial even in the north of France. $\mathrm{He}$ also produced one specimen from the Red Crag which had been in his possession for many years. He could not answer for the labelling but only for the locality and the condition of the bone, but from the peculiar way in which it had been cut and then broken it had all the appearance of having been artificially worked, but he should certainly only put it to a suspense account. With respect to one observation of Prof. Dawkins, that the oldest implements were ruder than the newer ones, he would remark that one cause why the implements of Creswell Cave were so rude was because they were made of quartzite, which could not be finished in the same way as flint. At Amiens the older high-level implements were often more finished and finer than those of the low-level gravel.

Col. Lane Fox wished to say a few words upon a point not yet touched upon in any of the papers which had been read, viz, the means by which valleys had been eroded, and the time necessary to accomplish it. The uniformitarian theory, by which it was assumed that all the work of excavating valleys had been performed by means of their rivers flowing under the same conditions as at present, had been a good deal modified of late years, and he thought he could add a few facts from personal observation tending to show that some modification of the theory was necessary. With respect to the valley of the Somme, there was evidence afforder by relics of the Roman and bronze age found in the peat in the bottom of the valley, that the river had not materially lowered its bed since those relics were deposited, and therefore it must have taken an enormous time to work out the whole valley by means of a river which flowed with the same eroding power as at present. The valiey of the Somme, however, was so comparatively narrow that it was possible the whole of it might have been eroded by such means, if sufficient time were allowed. But if it could be shown that the same conditions prevailed in other very much larger valleys where the work to be done was much greater, that would afford fair presumptive evidence that the truding force must have been greater. He could mention ore or two facks which showed that the Thames like the Somme had never shifted its bed since the bronze period. The first of these was that the river some way below Oxford, at the villave of Dorchester, made a great bend; the ground on one side was high, and on the other, in the space inclosed by the bend perfectly, flat and low; there was an ancient intrenchment running across this low ground from bank to bank, and converting the promontory formed by the bend of the river into a fortress. It had been ascertained by means of the relics, consisting of pottery, fints, bronze implements, \&c., associated with this intrenchment, that it was certainly as early as the bronze period, and perhaps earlitr, no relic of Roman work having been found there, althougb Dorchester, close by, was a Roman station. The intrenchment in order to serve its purpose must have re ted its flanks on the river at the time it was made, and the fact of their resting on the banks at the present time, although they are only a foot or two in height, showed that the river had not shifted or lowered its bed since the bronze age. Other evidence giving the same results was found in the same river lower down. Between Richmond and Battersea the Thames makes three or four bends in the comparatively flat bottom of the valley which is here more than four miles wide. He had found flint implements of the drift type deposited in sedimentary sand and gravel at Acton eighty feet above the present river, the discovery of which was communicated by him to the Geological Scciety and published in their journal. The river then since these implements were d posited must not only have lowered its bed eighty feet, but, according to the uniformitarian theory, must at each successive level have shilted its bed repeatedly so as to work out the valley here more than four miles wide. Yet bronze and stone implemen's bave been found in considerable numbers in all the various bends of the present river dredged up from the gravel at the bottom by the dredging machines that have been employed of late years, and proving that the river had neither lowered nor shifted its bed since the bronze period, but if anything it had risen since that time. Was it possible, he would submit, that at this rate of progress, if progress it could be called, the erosion of the valley could be attributed to the present river flowing under the same conditions as at present? But if, as believed by Prof. Buyd Dawkins and Mr. Tiddeman, man existed in these parts during the subsidence of the glacial epocb, that would account, he thought, for a much greater flow of water having passed down these valleys in palæolithic times than was the case at present. In the valley of the Solent the same class of evidence was obtained. Mr. Evans had shown what a large amount of depression and erosion must have taken place in this valley since drift implements were deposited on the hill at Southampion. The valley of the Solent, from Portsdown to the Isie of Wight, is nine miles wide, and we have evidence in the Roman fortress at Porchester bow littie it has changed in modern times; yet in the centre of this valley near Southsea common, Col. Fox had some years ago discovered a flint station of the neolithic age, including celts, scrapers, and flakes in great abundance, the site of which was less than ten feet above the present high-water mark, showing that fint implements continued to be fabricated in the valley after land and water had assumed its present distribution. All these facts, he thought, favoured the opinion that powerful eroding forces must have been at work before that time. The very valuable papers which had been read treated only the geological aspecrs of the question, but as the President had observed there were ethnological and sociological problems to be solved, how long would it have required for the various races of man to diverye, and the earliest traces of culture to be evolved? He truste 1 that even if no other result came of the conference it would show that we hat not yet exhausted the subject.

Prof. A. H. Sayce had to confess that the evidence of language as regarded the antiquity of man was not so decisive as that of geology. Under certain conditions the vocabulary of a language changed rapidly, under other conditions it changed slowly. The grammar of a language may be said to change never, and its structure to change very rarely. If these conclusions were applied to two or three of the principtl families of speech, the results would be sumething like this: Take the Semitic class of language; ; by means of the Assyrian monuments we are able to ger back to 2000 B.C. for a starting point, when those languages were pretty much as they are today. Scarcely any of the structure, or grammar, or vocabulary has changed, but it is plain enough that they pre-supposed several earlier stages of existence, and when compared with the grammar of the old Egyptian there was a time when the parent 
language seems to have been the parent also of the old Egyptian. But in order to allow for the changes that had taken place in the structure of the Semitic languages, and the structure of the Egyptian language, we must assume a very great period of time. With regard to the Aryan family, the different dialec's could be traced back to the parent speech spoken in some part of Western Asia. That parent language could be restored by comparison with the later languages and dialects. In all points that parent speech was as fully developed as Sanscrit, or Greek, or Latin, the people who spoke it were in an advanced stage of civilisation, and the language itself was in a highly advanced condition. When the grammatical details of the language were analysed, it became quite plain that it was the product of a long series of successive stages of growth. Take another language, the old language of Chaldea. The earliest monuments that contained that language were between 3000 and 2000 B.C. On these monuments the language appeared in a stage of the most utter decline and decay. Therefore there was evidence of a language which had behind it a long and undetermined past. If, as several scholars believed, that language belonged to the Ural-Altaic fami $y$, in order to get back to a period when those languages were one and the same, they must suppose an enormous period of time. Tnere was another consideration connected with the evidence of language. It . would seem that most languages, whatever their present structure might be, were at one time in a condition similar to that of the Esquimaux language at the present time, that is to say, a time when as yet the single word is not distinguished from the sentence as an independent unit, but forms part of the sentence in which it is embodied. In the case of languages so highly developed as, say, the Aryan languages, in order to get back to a time when those languages were in a condition similar to the present condition of the Esquimaux language, they must allow not hundreds but thousands of years. Those were the conclusions to which the present investigations of language would appear to point.

Mr. T. K. Callard, referring to the outline of the head of a horse, drawn upon a bone represented as belonging to the palæolithic age, found in association with extinct animals, said they had always been led to think that palæolithic man was a rude savage who could only chip his flint implement, but who could not smooth it (that would indicate the neolithic period), but they were now getting evidence of a different character. They had $h \in$ ard of a bone needle being found in the cave-earth, which at once suggested a step in civilisation, as men did not make bone needles unless they intended to use them, and that would lead their thoughts to a palæolithic tailor. In that very cave were found traces of a no mean artist, for not one man in three at the present time could make a sketch like that of the horse. It struck him that that Royal Academician of the palreolithic age had for his model a horse with tis mane clipped, which indicated another stage of civilisation. Were they justified in saying that because the remains of mammoth and woolly rhinoceros were found in close proximity to the remains of man, therefore man lived at such a remote period? He was inclined to think that it proved not so much the antiquity of man, as that the extinct mammalia were more modern than they are supposed to be. The works of man being found with the remains of the extinct mammalia, tells nothing of the period of man's existence, unless it is also proved when the mammalia referred to became extinct; of this there was no proof adduced, and therefore, to his mind, the argument for man's antiquity based on the contemporaneity of man and the extinct mammalia has not been sustained.

Mr. Harrison said the palæolithic character of the flint implements found at Cissbury in connection with the remains of exist ing fauna, including goat and pig, showed that the form and finish of prebistoric tools and weapons were not of themselves a safe criterion of age: Though the earliest implements would necessarily have been the rudest, the converse was by no mean true. There were doubtless art-centres in early times, as there are now, and Cissbury would not appear to have been one of them, but rather belonged to the far.larger class of village manifactories. Some of the pits, he wished to say as the result of personal observation, may have been opened but a short period before cur era. : Their age does not directly affect the question of the antiquity of man in this country, which depends for its solution on gealogical facts.

The President, Mr. Evans, in summing up, said the questions principally discussed, were-In the first place were they to assign any implement found in this country to a pre-glacial or inter-glacial period? or must they restrict them to glacial period? Some of the implements found in the river gravels were made from stones derived from glacial drift, and were therefore clearly post-glacial. The characteristic forms of the implements gave a guide by which they might fairly argue that oihers of a similar character belonged approximately to the same date. Some implements were very persistent in their type; but if in a certain part of England postglacial implements were found associated with a certain fauna, and in another part the same forms of implements were found alone, these also would appear to be post-glacial. There were certain distinctions to be pointed out in cave-deposits. In the cave described by Prof. Dawkins there were a succession of beds, and he thought it was in the upper beds of more recent date that the relics of the tailor and the artist were found. Looking at the enormous lapse of time comprised in the palæolithic period, which was evidenced by the amount of time requisite for the erosion of river valleys, he thought they would eventually be able to. establish some chronology. If they could form any idea of the amount of time requisite for the excavation of a valley such as the valley of the Thames, they could approximately estimate the antiquity of man in this country, but for the last 2,500 years the variation of the river bed and its level were practically nothing, and therefore they were entirely at a loss without falling back on some hypothesis as to variations in the climate. It was difficult to say with certainty whether the implements discovered abroad in reputed miocene and pliocene beds were of necessity worked by the hand of man, and whether they had in all cases been found under the circumstances which were attributed to them. With regard to the other deposits by which the early existence of man had been traced, such as the skull alluded to by Prof. Rolleston, if it was found with a highly-finished spearhead, he (the speaker) could not regard it as of pleistocene date. The evidence of cut bones was by no means satisfactory. Some of those incisions were probably induced by natural causes. Some present might remember a pair of horns of an Irish elk which by mere pressure were embedded in each other. Still, all such evidence should be carefully collected, and it would become to a certain extent accumulative. The question as to the distinction between the glacial period in the South of England and that of the North was of very great importance. If geologists carried back the early appearance of man in this country to a time but littie removed from the glacial period, they might safely infer that he must have existed in other parts of Europe at a much earlier period.

As this interesting discussion could not well be postponed, and as the time at the disposal of the Conference was necessarily brief, it now only remained for the three principals to reply to any objections that may have been raised to their statements and arguments.

Prof. Boyd Dawkins said that the first point to be con. sidered was the antiquity of man in the Victoria Cave, based upon a small fragment of fibula, and two fragments of goat's bones which presented the appearance of having been cut. The fibula seemed to hlm to be ursine rather than human, and in size came within a very little (two-tenths of an inch) of the circumference of one of Ursus spelaus from Lozère. With regard to the goat's bones, he shared the opinion of Mr. Davies, of the British Museum, that they are not fossil, but recent, in other words, he did not bel:eve that they were originally imbedded in the stratum containing the remains of the hyæenas, but were derived from an upper stratum of post-Roman age in the cave, in which they are exceedingly abundant. The goat hitherto has not been found in any pleistocene strata in this country or in France, all the repeated cases of its occurrence turning out on examination to be the result of the mixing of two suites of animal remains, the one pleistocene, and the other historic or pre-historic. This is yery generally done by the workmen, and this was probably the case in the Victoria Cave. But if these equivocal data be assumed to prove that man was living in this district while byænas occupied the cave, the evidence is still unsatisfactory as to their pre- or post-glacial age. The hyæna stratum itself appeared to him, while the explorations were under bis direetion, not to be of clearly defined pre- or interglacial age; and his doubts as to this point were, he believed, shared by Prof. Hughes. He further remarked that the rein. deer found in the hyæna stratum bad been omitted from $\mathrm{Mr}$. Tiddeman's list of species. The rudeness of the palrolithic implements in the Cresswell caves from the lower strata as compared with the more highly finished ones found above them seemed to him to imply a progress in the arts in that district. 
A. firivi, the more highly finished should succeed the ruder implements, although of course many cases of their being mixed toggether were on record. Into the other avenues of discussion he would forbear to enter.

Prof. Hughes, in reply, said that he wished the subject had been divided, so that they might have considered separately the different parts of the evidence and the different sources of error which had still to be eliminated. For instance, be thought it would be very well if they could have an exhibition of, and discussion on, the various ways in which nature breaks, cuts, and otherwise marks bone and stone as well as of various ruder forms known to be the result of human agency, so as to get clearer jdeas as to what might really be taken as evidence of design. He pointed out that the measure of the antiquity of the deposits containing the remains of man depended chiefly upon the time it would take to bring about certain geographical changes, either assuming that surrounding conditions had practically remained the same, or allowing for such differences as must have occurred, and of which we can estimate the effect. Applying this, while he agreed with Col. Lane Fox's remarks on the slow rate of waste of the Thames valley, he felt that we must make a very considerable allowance for the probability that during the period from the bronze age to our own man had interfered far more with the free course of the river than during ail previous time. Nature might also entirely change the rate of waste in such a case by a gentle upheaval or depression causing the more rapid or slower cutting back of the stream. With regard to the existence of depressions in non-calcareous strata he thought we could detect two ways in which they were formed. One by the forcing out of the plastic material all round the mass of gravel or clay thrown on it, and another when the gravel worked down into the puduled surface of a clay, the softer portions of which oozed up between the sinking stones. In all the cases which had come under his observation in which such phenomena occurred above paleolithic beds, the last appeared to be the explanation, as a!so in most cases where it was the only evidence for the more southerly extension of glacial phenomena.

With regard to the Victoria Cave, be thought that the evidence was as yet decidedly arrainst the pre-glacial age of any of the derosits containing even a suspicion of man. He believed that the deposits along the sides and in the side chambers of a limestone cave were frequently newer than those in the main cave, as the carbonated water, being thrown off the clay, must work the sides down. Whatever might be the age of the boulder clay on the floor at the mouth of the cave, he believed that the thin layer which occurred in the talus had iallen out of a pipe of which there were plenty in the limestone above, and that this clayey bank had ponded back the flood-waters and caused the accumulation of mud in the talus inside and the formation of the lami. nated clay.

Mr. Tiddeman ${ }^{1}$ had thought it unnecessary on this occasion to call altention to geological minutiæ at the cave mouth, but as Prof. I lughes bad raised the question of the age of the boulder clay there he was bound to follow hin. Prof. Hughes said the boulder clay fell from the cliff at a time long subsequent to the date when the bones were deposited, but in drawing his section he had omitted a very important feature. They had to dig through twenty feet of talus before they came to the boulder clay, at the back of which was the hyæna bed; that represented a very considerable lapse of time since the boulders were deposited there. If the boulder clay fell at a subsequent period how was it that it was at the base of all the talus and not mixed up with it. If it fell before the talus began to form it might practically be considered of glacial age. As regards the reindeer in the lower bed, only one very doubtful specimen had been found since he had had charge of the excavations. The chief matter to be considered was whether this fauna which had been found in Europe and in England with human handiwork, occurred at a time which could ise correlated with certain great physical events. All the facts which he had noticed seemed to harmonise with the idea that there had been in England two well-marked glacial periods, and these both prior to the much lesser event of the upper boulder clay of Lancashire. For instance, the boulders made into implements which Prof. Hughes had referred to in Pontnewydd Cave, need not have belonged to the latest glaciation of that country. Mr. Tiddeman would not dispute the fact of a fibula making its way down into the earth, especially after Prof. Rolleston's experience, but in the Victoria Cave it would have

I In the abstract of Mr. Tiddeman's paper, p. 7o, line 4o, non-gravcls sliould be riter-sravels; line 44 , ther post-glacial should be there postglacial. great difficulty. If it were soft mud it might have a chance of getting down, but if it were modern other modern things would go down with it unless it had a start. [Prof. Rolleston said it was pointed at both ends.] Mr. Tiddeman did not think there was a possibility of its working its way down. There were large blocks of stone and beds of stalagmite which had to be blasted in getting down to it. He hoped geologists would bear in mind as new facts cropped up, the suggestion that we had had two glacial periods.

\section{THE GREENWICH OBSERVATORY REPORT}

THE Report of the Astronomer-Royal at the annual visitation on Saturday contained nothing extraordinary with respect to the ordinary work of the Observatory. With reference to ex. traneous work, there are one or two points worthy of notice.

First, as regards the operations for the transit of Venus, the Astronomer-Royal reports as follows :-

The computing staff under Capt. Tupman has by degrees been reduced to two junior computers within the Observatory; and one or two computers external to the Observatory, who are em. ployed on large groups of systematic calculations, for which they are remunerated by tariff. The principal part of the calculations remaining at the last report was that applying to the determination of the geographical longitudes of fundamental stations. At the moment of my writing, the last of these (the longitude of Observatory Bay, Kerguelen) is not absolutely finished; but I trust that it will be so before my presentation of this report; and then I shall be in position to offer the first determination of correction to parallax from eye-observations of the transit.

The method of determining the geographical longitude of the principal station in each group by vertical transits of the moon has been found very successful at Honolulu and Rodriguez. For stations in high south latitude, horizontal transits are preferable; for Kerguelen, as I have mentioned, the work is not quite completed. (It will be remembered that the longitude of Mokattam, the principal Egyptian station, was determined by telegraph.) The corrections to the moon's tabular places have been deter. mined with much care from meridional observations at the prin. cipal European observatories.

The differences of longitude, or the relations of clock-times, within the groups of stations, are ascertained.

These calculations must be followed by the preparation of the factors of errors of various elements. Little progress is made in these ; the work will not be heavy.

No further advance is made in the photographic reductions. The work is large, but it is simple, and will not be oppressive.

Second, as regards the numerical lunar theory :-

In the algebraical theory an alteration has been made, by the substitution of the equation of radial forces for the equation of vis viva. Nearly all the numbers had been computed, and the additional numerical operation was small.

The numerical calculations of the factors of symbolical variations are advancing; and the computations of the perturbing side of the equations, with due attention to the terms requiring extension of decimals, are in progress.

The numerical errors to which I alluded in the last report are corrected; and I do not think that any systematic error now remains.

With the view of preserving, against the ordinary chances of destruction or abandonment, a work which is already one of considerable magnitude, I have prepared and have printed as Appendix to the Greenwich Observations (with additional copies as for a separate work) the ordinary equations of lunar disturbance, the novel theory of symbolical variations, and the numerical developments of the quantities on the first side of the equations. The last of these will ultimately require some additions for the terms whose magnitude is increased (in algebraical development).

The work is perhaps somewhat larger than $\mathrm{I}$ anticipated, and the regularity of its progress has been disturbed by very frequent interruptions of my owm attention, occasioned chiefly by annoying occupations on the transit of Venus. I trust that it will in future go on in a more orderly and more rapid way.

Sir George Airy concludes his report with the following general remarks :-

The subject which, I think, must first present itself to the mind of anyone who has traced the history of the observatory is the increase in the number and the fulness of our occupations. 